\title{
Plut. Ti. Gracch. 16, 1: a Gracchan law on appeal?*
}

\author{
Natalia A. Kuznetsova \\ St. Petersburg State University (SPbSU), \\ 7-9, Universitetskaya nab., St. Petersburg, 199034, Russian Federation; \\ st042702@student.spbu.ru; ku02@yandex.ru
}

For citation: Natalia A. Kuznetsova. Plut. Ti. Gracch. 16, 1: a Gracchan law on appeal? Philologia Classica 2019, 14(1), 56-67. https://doi.org/10.21638/11701/spbu20.2019.104

According to Plutarch, Tiberius Gracchus announced during the election campaign of the $133 \mathrm{BCE}$, that he would pass a number of laws, and among them - the law granting the right of appeal to the people (provocatio) àंò $\tau \tilde{\omega} \nu \delta \iota \kappa a \sigma \tau \tilde{\omega} \nu$. Ti. Gracchus has died before he passed the alleged law. Besides Plutarch, his last reform programme is attested only by Cassius Dio, who mentions no law on appeal. The whole programme is very similar to the laws of Gaius Gracchus, and there is suspicion, that it consists of the laws of Gaius which were ascribed to Tiberius to depict him as a power-seeking demagogue. What could be the aims of the law on appeal and what it meant exactly? Firstly, both Gracchi could consider an appeal against the senatorial extraordinary commissions which would protect the Gracchans against political persecution. This measure seems to be more appropriate after the advocates of Tiberius Gracchus were prosecuted in senatorial courts. But Gaius Gracchus, instead of it, prohibited appointing the extraordinary courts iniussu populi. Secondly, if the aim was to gain the electors, Tiberius could promise them appeal against murder courts, though it would be pernicious for the public order. Finally, in all other cases the bill on appeal would be of no use for the Gracchans, but would make them a good target of criticism. Such a measure could well be invented by an anti-Gracchan source.

Keywords: provocatio ad populum, Gaius Gracchus, Tiberius Gracchus.

Provocatio - an appeal to the Roman people - has long been a matter of debate. Th. Mommsen saw it as part of any comitial trial which he regarded as "zweistufiges magistratisch-komiziales Verfahren", where provocatio might be allowed in cases of iudicatio. The iudicatio was for Th. Mommsen some sort of judicial verdict by a magistrate. This

* I am deeply indebted to the editors of Philologia Classica for their great help and tolerance and particulary to M. M. Pozdnev for his constructive criticism.

(C) St. Petersburg State University, 2019 
scheme can be deduced from some theoretical notes of our sources, ${ }^{1}$ but it is difficult to apply it to the majority of both the comitial courts and the precedents of provocatio. For in the most comitial trials no appeal is attested, and the most cases of appeal concern not iudicatio, but coercitio - the penalties which a magistrate could impose without any trial for the benefit of public order. ${ }^{2}$ On this fact is based the alternative view, namely that that provocatio was not required for a comitial court, and that it was possible against coercitio. ${ }^{3}$

A curious instance of an attempt to introduce provocatio as a means of challenging court rulings can be found in Plut. Ti. Gracch. 16, 1: describing the tribunal elections of the summer of $133 \mathrm{BCE}$, in the course of which Tiberius Gracchus attempted a re-election and, according to Plutarch and Cassius Dio (24, Frg. 83 (Dindorf) $=84$ (Boissevain) 7-8), put forward a number of reforms. Before we get down to the discussion of the law on provocatio itself, it is worthwhile to cite both testimonies about the election programme and to assess their reliability, Plut. Ti. Gracch. 16, 1: ${ }^{4}$

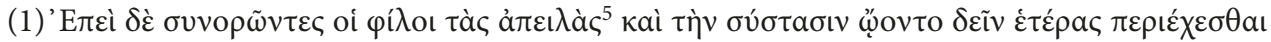

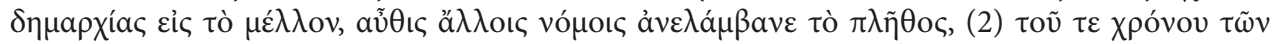

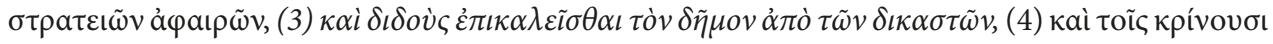

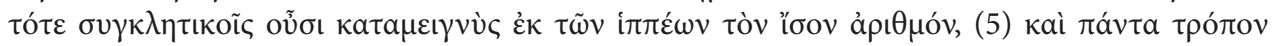

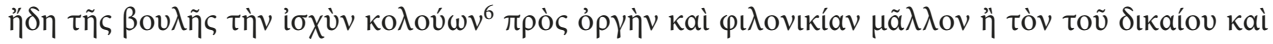

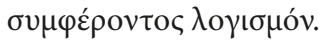

"(1) And now his friends, observing the threats and the hostile combination against him, thought that he ought to be made tribune again for the following year. Once more, therefore, Tiberius sought to win the favour of the multitude (plebs?) by fresh laws, (2) reducing the time of military service, (3) granting appeal to the people from the verdicts of the judges, (4) adding to the judges, who at that time were composed of senators only, an equal number from the equestrian order, (5) and in every way at length trying to maim the power of the senate from motives of anger and contentiousness rather than from calculations of justice and public good."

Cassius Dio 24, frg. 83 (Dindorf) $=84$ (Boissevain), 7-8:

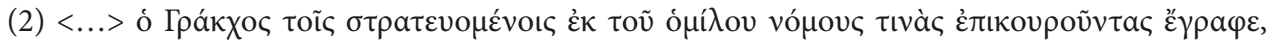

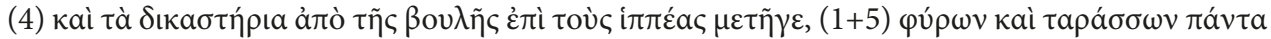

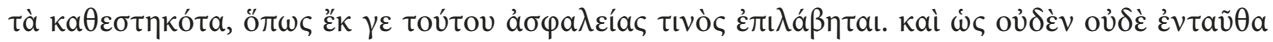

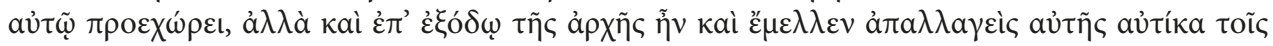

${ }^{1}$ E. g. Pompon. Dig. 1, 2, 2, 16; Cic. De Leg. 3, 6 and 27. See Mommsen 1899, 166-167; ${ }^{3} 1887,138,1 ; 167,1$.

2 The only exception is the court of duumviri perduellionis, where provocatio is well attested (Liv. 1, 26, 5-14; Cass. Dio 37, 25, 4-28, 4). There were attempts to refute the evidence because of an alleged contradiction between it and Cic. Rab. Perd. 12. See Kuznetsova 2017.

${ }^{3}$ Mommsen's views (albeit compressed) can be gathered from Mommsen 1899, 151-174; ${ }^{3} 1887,162-$ 169. For objections, see Bleicken 1959. Lintott 1972, 226-227 gives a brief abstract of the polemic. This might be enough to understand the essential points.

${ }^{4}$ For the purposes of clarity, we split the text into passages numbered in round brackets.

${ }^{5}$ Plutarch seems to be neglecting the threats of prosecution Tiberius could face once he stepped down as tribunus plebis; Cassius Dio mentions these in the passage cited, as does Appian (B. Civ. 1, 13, 57). In what is above, Plutarch is dealing with the outrage Tiberius encountered in connection with the will of Attalus and renunciation of Octavius; it is possible that ả $\pi \varepsilon \imath \lambda \alpha^{\prime}$ imply a real danger, not verbal abuse.

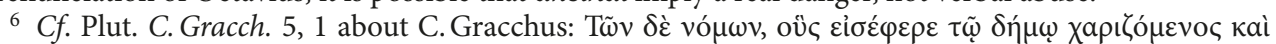

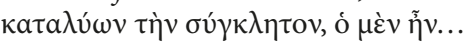

7 Transl. Perrin 1988. 


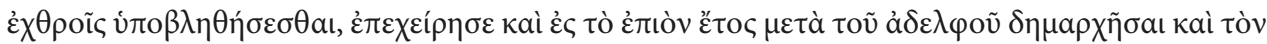

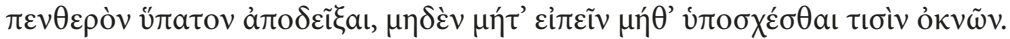

" $(2)<\ldots>$ Gracchus was proposing certain laws for the benefit of those of the populace serving in the army, (4) and was transferring the courts from the senate to the knights, (1+5) disturbing and overturning all established customs in order that he might be enabled to lay hold on safety in some wise. And when not even this proved of advantage to him, but his term of office was drawing to a close, when he would be immediately exposed to the attacks of his enemies, he attempted to secure the tribuneship for the following year also, in company with his brother, and to appoint his father-in-law consul; and to obtain this end he did not hesitate to make any statement or promise anything whatsoever to people. Often, too, he put on mourning and brought his mother and children into the presence of the populace to join their entreaties to his."

The evidence for the last reform programme of Tiberius Gracchus is slim: the law on provocatio is mentioned only in Plutarch; ${ }^{9}$ both attest to the law on the reduction of the term of military service and on lists of jury courts which are unattested in the rest of our extant sources. ${ }^{10}$ The relevant passage in Appian, one of the main sources on the life of Tiberius Gracchus, does not say a word about these laws (B. Civ. 1, 14, 58-17, 72).

Cassius Dio seems to be locating these drafts in the time prior to the election campaign. Both he and Plutarch can speak of the laws, which Tiberius has put in action. But Plutarch associates these drafts with the time of the election campaign. He could just as well imply not the reforms carried out, but an election programme. Such explanation is more feasible: there is no evidence either for the application of these laws, or for their revocation, while the law on the transferring of the courts to equestrians was passed only by Gaius Gracchus. Thus we suppose that both Plutarch and Cassius Dio speak of the election programme of Tiberius Gracchus which probably remained unimplemented.

What catches the eye here is the similarity this programme bears to the laws introduced later by Gaius Gracchus: lex Sempronia militaris of 123 BCE differs from the draft of Tiberius, but both may be considered to be moving in the same direction; ${ }^{11}$ one can only regret the loss of the details of the Gaius Gracchus' law concerning the lists of jury courts in Cassius Dio, but in Plutarch - our only source describing the relevant drafts of both brothers - the

8 Transl. Cary 1989.

9 Rotondi 1912, 300 suggests a comparison between Plutarch's testimony and Macr. Sat. 3, 14, 6 Eyssenhardt, or else with the law on the makeup of court commissions. Both comparisons are unlikely, see the next note.

10 Macrob. Sat. 3, 14, 6 Eyssenhardt mentions the speech of Scipio Aemilianus contra legem iudiciariam Tib. Gracchi. Meyer ${ }^{2} 1842$, 191-192 refers this testimony to a bill on the makeup of law courts and concludes that it was voted down thanks to the efforts of Scipio. Rotondi 1912, 300 accepts this point. But Scipio was in Numantia during the whole tribuneship of Tiberius Gracchus (Münzer 1900, 1456; Schulten 1936, 1260). Thus, this speech could only refer to a law, which was in force after Tiberius' death. It could be the law granting the triumviri agrarii the power to decide on the legal status of contested plots of land (Rotondi 1912, 300 (lex Sempronia agraria altera); for a detailed discussion see Lapyrenok 2016, 36-52 [Р. В. Лапыренок. Наследие аграрного закона Тиберия Гракха: земельный вопрос и политическая борьба в Риме $20-x$ z2. II в. до н.э.]. As a result of the efforts of Scipio these powers were transferred on to the consul of 129 BCE. C. Sempronius Tuditanus (Broughton 1951, 504), which makes it plausible that the speech dates to that very year. Holding to this point are Malcovati 1930, 1, 120-121; Gabba 1958, 60-61; Münzer 1900, 1457.

11 Is mentioned in Plutarch G. Gracch. 5, 1; Diod. 34/35, 25. It is possible that this law was meant by Asconius In Cornel. 54 Stangl to be among the laws revoked by M. Iunius Silanus. See Marshall 1985, 242. We owe this prompt to V.K. Khrustalev. 
essence of their proposals is the same. ${ }^{12}$ As well in other sources: Velleius Paterculus (2, 2, $3)^{13}$ ascribes to Tiberius Gracchus the initiative of Gaius to grant citizenship to Italics. ${ }^{14}$ It looks like as if some laws of Gaius were ascribed to Tiberius. Anyway, bills which were not passed as laws, could have easily been distorted already in the ancient tradition. Whatever was the source of Plutarch and Cassius Dio, their censorious tone makes an impression that this was a source hostile to the Gracchi, trying to ascribe to Tiberius certain radical proposals that could have served as a justification of his murder. All this makes the evidence of Plutarch and Cassius Dio suspicious. ${ }^{15}$ But it can not be simply refuted. Certain discrepancies between the sources as well as the silence of Appian concerning these laws do not imply, that the laws were invented after Tiberius' death. ${ }^{16}$ And it would be unwarranted to say, that the laws could not be conceived by Tiberius because they are too similar to the laws of his brother or because the evidence reflects an anti-Gracchan source.

If the Plutarchs's source invented the bill on provocatio, it is natural to think, that the invention was based on some project of Gaius Gracchus, the same way as the rest part of the election programme. ${ }^{17}$ The bill on provocatio could have been conceived and left unfulfilled by both brothers as well as their advocates. Our task is to work out to which ends the law on provocatio could have served them. ${ }^{18}$ Chronologically, we are working between 133 BCE, the year Tiberius was voted tribunus plebis, and 122 BCE, the death of Gaius.

Which procedure could be implied in the Gracchan bill on appeal? The tradition gives no detailed account of the procedure, which was needed in case of provocatio. Its reconstruction depends on one's understanding of provocatio. For Th. Mommsen provocatio

12 Plut. Ti. Gracch. 16, 1 et C. Gracch. 5, 2-3. See Fraccaro 1914, 154-155, who notes, that the description by Cassius Dio is identical with Liv. Epit. 60 (on Gaius' law). Fraccaro's hypothesis that the Tiberius' bill on provocatio might reflect an earlier version of the same judicial law of Gaius, is puzzling. It is based on the assumption, the Tiberius' bill on appeal might be designed on behalf of the equestrian order, namely to give them protection in repetundarum cases; Fraccaro seems to suppose the same for the judicial law of Gaius. Cf. further, n. 37.

13 Rotondi 1912, 300 wrongly points to App. B. Civ. 1, 23, 98-100 as a mention of this bill of Tiberius Gracchus; in fact, it refers to Gaius Gracchus. Lange ${ }^{3} 1879,685$ points to App. B. Civ. 1, 21, 86-87, in fact, describing the events of 125 BCE (rogation of consul Fulvius Flaccus, see Rotondi 1912, 306).

14 On this bill, see various suggestions of: Münzer 1923a, 1392; Gabba 1958, 79-80; Sherwin-White 21973, 139-149; Stockton 1979, 185-195. The relevant sources: Vell. Pat. 2, 6, 2; Plut. G. Gracch. 5, 2; App. B Civ. 1, 23, 98-10. This bill has never been passed law.

15 See criticism of Fraccaro 1914, 145-161, especially 154-160. Part of his argumentation resting on a psychological portrait of Tiberius drawn by Appian cannot, in our opinion, be verified; to counter his argument that consistent policy aiming at segregation of senators and equestrians belongs to Gaius and is impossible for Tiberius (op. cit. 159-160), one may object that the latter, feeling the danger, could seek support of all strata of society.

16 Münzer 1923b, 1419-1420 on these grounds accepts the quoted testimonies of Plutarch and Cassius Dio. Stockton 1979, 72-74 observes, that it is impossible either to corroborate or to refute them, and suggests (ibid. 68, n. 26) that this programme may be a part of a sweeping reform project, conceived by Tiberius shortly before his death. Mommsen 1899, 476 accepts Plutarch's note on the bill concerning provocatio; he does not discuss the other points of Tiberius' programme. Lintott 1972, 240: "Whether Plutarch is relating a genuine proposal of Ti. Gracchus or one that appeared in his brother's propaganda, there is nothing essentially implausible in it." The main reason for this point of view appears to be the hypothesis (ibid., 239-240) that provocatio against court rulings was not forbidden by law and was acceptable in the eyes of the Romans. Lintott's later judgement concerning the programme of Tiberius Gracchus (Lintott 1994, 69) is far more careful.

17 To this we return at the end of the present article.

18 The points of the programme as related by Plutarch and Cassius Dio may come from different sources, but they would be worth discussing as a whole. We have to forgo this opportunity and concentrate on provocatio which interests us most, while a broader approach would far outreach the proposed study. 
by definition led to a comitial court. ${ }^{19}$ But according to J. Bleicken's point of view, it could be a plebiscitum as well. ${ }^{20}$

Iudicium populi was a procedure inherently cumbersome and easily disrupted. Cf. Cic. De Dom. 45:

ne improdicta die quis accusetur, ut ter ante magistratus accuset intermissa die quam multam inroget aut iudicet, quarta sit accusatio trinum nundinum prodicta die, quo die iudicium sit futurum, $<\ldots>$ si qua res illum diem aut auspiciis aut excusatione sustulit, tota causa iudiciumque sublatum est.

"To prevent the accusation of anyone without notice being given, but demanding that the magistrate shall lay his accusation thrice, with an interval of a day between each accusation, before he inflicts a fine or gives his verdict, while the fourth accusation shall convey an intimation that the trial will after three (eight-day) weeks from the day on which it is laid; $\langle\ldots\rangle$ if the day named is cancelled by reason of unfavourable auspices or of any other excuse, the whole process and the trial itself are also cancelled."21

If the Gracchan bill prescribed not a trial, but a rogatio on pardoning of the accused, the time taken by the procedure would be only a little shorter. Promulgatio was to take place within trinum nundinum before the voting. In the 1st c. BCE this period was laid down as law (lex Caecilia Didia 98 BCE: e. g. De Dom. 41), and there is no reason to suppose that prior to that it was not done likewise by custom..$^{22}$ In order to be functional in the case of provocatio, a clause specifying a magistrate to file rogation should be written

19 This can be supported by the vocabulary used in the context of provocatio, though allowing for a non-technical interpretation: certare ad populum (e. g. Liv. 1, 26) or iudicium populi (e. g. Liv. 8, 33, 8). As

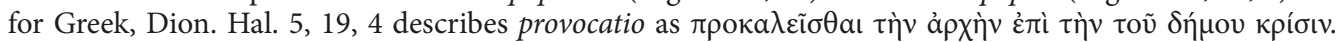
Provocare and appellare in post-classical language are synonymous and imply a court of last resort (e. g. Tac. Ann. 14, 28); provocare often means "to take to court" (OLD s. v. 6).

20 J. Bleicken suggests, that provocatio stemmed from a spontaneous appeal of a plebeian to his comrades: if the tribunes of the plebs saw, that their ius auxilii in this case could be ignored, they summoned the plebs and demonstrated by means of a plebiscite, that people were ready to defend their comrade. See Bleicken 1959, 345-356. The precedents of provocatio against the main pontiff seem not to correspond the procedure of the comitial trial. See Bleicken, 1957, 462-468 with the list of the cases ibid. 450-457; and 1959, 341-345. One should consider, if the description of the cases in the tradition fits the procedure and if the described procedure was the formally correct consequence of the provocatio and not a compromise reached in an insoluble conflict between the religious norms and the citizen's right of appeal. I must concede that my own quotation of Liv. 40, 42, 9-11 as a iudicium populi (Kuznetsova, 2017, 295-296) is open to doubt. Note that Bleicken admits no fixed procedure for provocatio; a plebiscite might be passed sometimes, not always, and only before the right of appeal was recognized by the laws. Because, as he argues, the laws on appeal had as consequence not the exercise of it, but the fall of the appealable punishment out of use: this punishment began to be prescribed only by means of iudicium populi. See Bleicken 1959, 2462-2463. But it's unlikely that the laws ordered a magistrate to repeal the punishment, if it was appealed against. They must have prescribed some procedure. And it might be not a voting on a plebiscite: a law ordering to pass another law looks quite strange. Lintott 1972, 239-240 suggests a voting on a rogation for the bill of Antonius (Cic. Phil. 1, 21-26). As Lintott himself points out, a proposal of pardoning the accused would contradict the norm privilegia ne inroganto.

${ }_{21}$ Trans. Watts 1923 with my corrections. Cloud 1994, 501 suggests that the formal procedure described by Cicero was not adhered to at all times. He corroborates his cause quoting, without any comment, two passages from Livius: Liv. 25, 3 and 43, 16. Cf. Briscoe 2012, 444, who thinks, that Livy (in the latter passage) describes the trial in inappropriate way. We suppose rather that Livy simply ignores details not relating to the voting. We see nothing inappropriate in it. In any case, we see no reasons to believe that comitial courts could be "speeded up". The quoted passages of Livy do not imply it.

22 Wesener 1962, 1239-1241. 
into the Gracchan law. Comitial court is in an advantage of having as default prosecutor the praetor having as a provincia the court which pronounced the sentence appealed against to the people.

In whatever form the people of Rome made a decision in cases of appeal, the procedure might take a lot of time. Any obstacle could have had the acquittal of the accused as a consequence, if it was a comitial court. ${ }^{23}$ And if it was a voting on a proposal, the consequences of an omen could become a matter of a heated discussion: should the convected be acquitted or not. ${ }^{24}$ The more trivial the court case, whose sentence was made eligible for a provocatio, the more inconveniences it was likely to breed. Either the court would fall out of use, or else provocatio would become futile, no longer an inviolable and sacred right of a Roman citizen, but an empty sound.

What exactly does ảંò $\tau \tilde{\omega} v \delta \iota \kappa a \sigma \tau \tilde{\omega} v$ mean? The following variants are possible:

- provocatio against a private court appointed by a praetor;

- provocatio against legis actiones;

- provocatio against a legis actio sacramento in criminal cases; ${ }^{25}$

- provocatio against a conviction before a standing commission (quaestio perpetua); ${ }^{26}$

- provocatio against a condemnation before an extraordinary commission (quaestio extraordinaria);

— appointed by the popular assembly;

- appointed by the senate. ${ }^{27}$

An appeal in any legis actio, as far as we know, has not as yet been suggested; it is well worth considering. The introduction of provocatio against legis actiones would mean a popular assembly labouring under a burden of issues of trifling importance and a multitude of checks for the party bringing legal action. In particular, that would have grave consequences for the business life in Rome.

In civil legis actiones it is difficult to imagine a right for provocatio due to one more reason: in the Roman tradition, provocatio is viewed as a safeguard of the liberties of a Roman citizen against the implementation of certain severely grave punishments, while in legis actiones the issue at stake was at the most the loss of property, and this not as form of punishment, but a necessity to cover the expenses of the opposite party.

It is easier to conceive a provocatio against legis actio sacramento in a criminal case, the existence of which was suggested by W. Kunkel. ${ }^{28}$ While the laws of the 12 Tables were in effect, it could have been possible that severe corporal punishments (talio) and capital punishment could well have been imposed, against which provocatio could be used. It is however questionable as to whether an introduction of such a provocatio could be attrac-

23 See De Dom. 45 quoted above. Cf. Kuznetsova 2017, 294-296 for some details.

${ }^{24}$ However, such details could be included into Gracchan bill on provocatio.

$25 \mathrm{~W}$. Kunkel conjectured their existence before the introduction of quaestiones perpetuae to substitute for the bipartite court with obligatory provocatio suggested by Th. Mommsen. See Kunkel 1962, 97-130; in

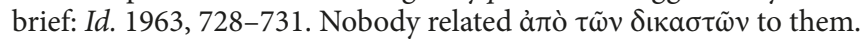

${ }^{26}$ Lintott 1972, 240 (cf. further, n. 33) may imply every form of quaestio, but his examples concern

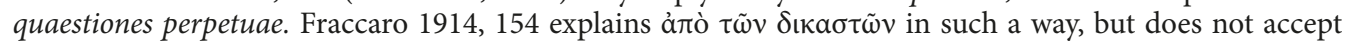
Plutarch's evidence.

27 Interpretation of Botsford 1909, 255.

28 See above, n. 26. 
tive to the general public; it seems to be too disruptive for public order, for the condemnation of the criminal in this case would be complicated. ${ }^{29}$

On balance, provocatio against "non-criminal" legis actiones is highly improbable; and in "criminal" legis actiones (if they existed) it could be attractive for lower strata, if they were not aware of the possible consequences of such a law. In this case the Gracchan bill can be explained only as a purely demagogic step.

The same might be said in the case of quaestio inter sicatios. ${ }^{30}$ Besides of it, we hear of only two quaestiones perpetuae in the 2 nd cent. BCE: quaestio repetundarum ${ }^{31}$ and de ambitu. ${ }^{32}$ The latter is not attested before 121, but suppose all the three existed. A provocatio against condemnation repetundarum would play into the hands of the senators. The lex Acilia repetundarum ${ }^{33}$ of the time of Gaius Gracchus allows to bring action against the majority of magistrates and the sons of those who are senators at the time of the trial; ${ }^{34}$ one can well imagine that an equestrian who went no further in office than aedilis, could be put on trial under this law, but mostly it had a bearing on senators. It is questionable, however, whether at an earlier date the laws were not somehow different. ${ }^{35}$ In the majority of the attested extortion trials of the 2nd c. BCE the defendants were former provincial governors; judging by a number of sources, by the 1 st $\mathrm{c}$. BCE it was common practice to hold them responsible for the actions of their underlings. ${ }^{36}$ It is evident that in this case

${ }^{29}$ It's often suggested that the process before quaestores parricidii included appeal to the people (see Wesener 1963, 803-806 (including literature)). The details of this process are unattested. Provocatio is conjectured on base of the analogy with the court of duumviri perduellionis, where the appeal is well attested (Liv. 1, 26, 5-14; Cass. Dio 37, 25, 4-28, 4), though very much debated (see Kuznetsova 2017). When we draw this analogy, provocatio should be the part of both procedures, - but they both would allow no acquittal (Liv. 1, 26, 7: absolvere ne innoxium quidem posse), and this might be the fact, which made an appeal indispensable. There was then no resemblance between the court of quaestores parricidii and quaestio de sicariis; even if there was an appeal to the people in the former, this makes no easier enacting of the right of appeal in the latter.

${ }^{30}$ It's attested for the 141 BCE: Cic. De Or. Fin. 2, 54: (L. Hostilius Tubulus, see Broughton 1951, 475) qui cum praetor quaestionem inter sicarios exercuisset, ita aperte cepit pecunias ob rem iudicandam ut anno proximo P. Scaevola tribunus plebis ferret ad plebem vellentne de ea re quaeri. About the quaestio inter sicarios see Kunkel 1962, $45 \mathrm{n}$. 171 and 1963, 736. The quaestio de veneficiis is first attested for 98 BCE, but could have existed before, see Kunkel 1963, 738-739.

31 Kunkel 1963, 736-737; Rotondi 1912, 292. Cic. Brut. 106 refers to it as the first quaestio perpetua.

32 Alexander, 1990 № 34-36 - the first cases ambitus quoted by him - are all dated 116 BCE, what makes the quaestio de ambitu likely to be established not long before. The testimonies quoted by Lintott 1972, 240, 75 do not attest quaestio (perpetua) de ambitu for the time of Gracchi: the earliest case is Plut. Mar. 5; Cic. De Or. Orat. 2, 174 describes the events of 97 BCE (see Leemann et al. 1989, 311), and the quoted passages of Livy - leges de ambitu from the first time of the 2nd c. BCE, that is, before the first quaestio extraordinaria (149 BCE, cf. Cic. Brut. 106).

${ }^{33}$ We accept the identification of the lex repetundarum tabula Bembina as lex Acilia. See Crawford 1996, 1, 51-52 and bibliography ibid. 39-40. The text of the lex Acilia is cited according to this edition.

${ }_{34}$ Lex Acil. I. 2. The passage is corrupt: Crawford 1996, 1, 95; Damon, Mackay 1995, 41, n. 17.

35 Cic. Rab. Post. 12-19 argues, that Rabirius should not be condemned lege Iulia de repetundis (59 BCE) even under the clause quo ea pecunia pervenerit: such a precedent would be dangerous for the equites, who were not indictable under this law (except for this clause). Concerning the lex Iulia see Kleinfeller 1914, 607-608; Damon, Mackey 1995, 44, n. 30. It seems that no lex repetundarum (at least since the Acilian law) infringed on the interests of the equestrian order: only the former magistrates were indictable. The situation might have been the same also before the Acilian law.

36 See Damon, Mackay 1995. Under the cases collected by Alexander 1990 before 76 BCE we are aware only of two precedents, which may contradict to their conclusions: № 94, prosecution of a legate, on which see Damon, Mackay 1995, 47, n. 42; and № 96, the prosecution of M. Aemilius Scaurus ob legationis Asiaticae invidiam under the lex Servilia (Asc. 21 C.; on the Servilian law see Berger 1925b, 2414-2415). 
the senators would have a vested interest in provocatio. But the Gracchi could not gain the majority of the senate by such a law. At best they could gain support of several politicians, but it is no less questionable: the condemnation in the extortion court was at this time rare. ${ }^{37}$ This fact makes the appeal dispensable also for the equestrians: if they wanted to support the magistrates active on their part in the provinces, they had more convenient means (e. g. bribery).

The second objection is purely of legal character: before the Acilian law the quaestio repetundarum was a legis actio sacramento, ${ }^{38}$ which did not specify any particular punishment - only the the recovery of losses; the Acilian law was the first to specify a penalty, namely the restitution of damages in duplum. ${ }^{39}$ Thus, any provocatio against the sentence repetundarum before the Acilian law would be a provocatio against legis actio sacramento discussed above. ${ }^{40}$

Finally, provocatio in the extortion court would have aggravated the position of the provincials and the Italic allies of the Romans alike. ${ }^{41}$ This would have caused violent opposition on the part of the latter, thus granting the senate a strong argument in propaganda. C. Gracchus defended the interests of provincials and allies; there is also some not very reliable evidence for Tiberius' intention to give citizenship to Italics (see above, 3-4). Would appeal in extortion courts contradict the course of Gracchan politics? This depends on whether the agrarian laws of Tiberius (Liv. Per. 58) did hurt the allies. This is a matter of debates. ${ }^{42}$ Anyway, there were heated conflicts between the agrarian commission and the italics. Thus the power to render a judgement on disputed parcels was transferred from agrarian triumvirs to the consul of 129 BCE C. Sempronius Tuditanus, who neglected the task. ${ }^{43}$ If the agrarian laws did not offend the allies, the law on appeal in extortion courts would do it and would not go with the other Gracchan laws, e. g. lex Acilia repetundarum. If the agrarian laws did, it would be highly unreasonable to exacerbate the struggle by the law on provocatio. Thus the law allowing an appeal in extortion courts could not be proposed by C. Gracchus and then be ascribed erroneously to Tiberius. And it is at least doubtful, that it could be submitted by the latter.

Quaestio de ambitu raises doubts on similar juridical grounds. In the last fifty years of the Republic, the earlier the law was passed, the milder was the punishment for bribery: lex Pompeia of $52 \mathrm{BCE}$ enforces not only the current punishment, but the court procedure;

This legatio is mentioned nowhere else. Cf. Marshall 1985, 134-136 for further discussion. Anyway, the most people prosecuted repetundarum were senators. Therefore we can't accept the hypothesis of Fraccaro 1914, 156-157, cf. 159 that the appeal in extortion courts would be attractive for equites.

37 Cf. Alexander 1990 № 8, 9, 23; Lintott 1994, 77; Cloud 1994, 507-508.

38 Lex Acil. 23 neive eum [quei condemnatus siet, quod cum eo lege Calpu]rnia aut lege Iunia sacramento actum siet aut quod h(ace) l(ege) nomen [delatum sie]t. Cf. Kunkel 1962, 12-13; Crawford 1996, 1, 101-102.

39 The exile was not a punishment but a method of avoiding it, $c f$. further, n. 53. For the penalty both in the Acilian law and the earlier laws see Lex Acil. 58-59 (de litibus aestumandis).

${ }^{40}$ We are grateful to V. K. Khrustalev for this argument.

${ }^{41}$ That the extortion court could be of interest for the italics, one may conclude from l. Acil. 1 [quoi socii no]minisve Latini exterarumve nationum... The text in brackets is conjectured by C. A. C. Klenze (see Crawford 1996, 1, 75).

42 Stockton 1979, 42-46 suggests, that the allies believed erroneously, that their rights were infringed: the cause was the misrepresentation of the agrarian law by the senate, For the contrary view cf. Lapyrenok 2016, 13-52. For him, C. Gracchus tried to compensate the losses of the allies by giving them civic rights (Ibid., 52-67; as to the rights of the Roman citizen he seems to take into account only the possession of public land; I am not sure, what he thinks of the right of provocatio (ibid., 67)).

${ }^{43}$ Cf. above, n. 10. 
lex Tullia of 63 BCE adds to the mentioned below a decade of exile; lex Calpurnia Acilia of $67 \mathrm{BCE}$ requires a life-long ban on running for any office and a fine; the Sullan law only suspended the eligibility for any office for ten years. ${ }^{44}$ One may surmise that before that, in the $2 \mathrm{nd}$ c., the sentences imposed were even milder. In which case a provocatio against them was of no use. ${ }^{45}$ To this, Polyb. Hist. 6, 56, 4 is an obstacle:

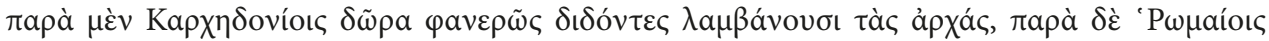

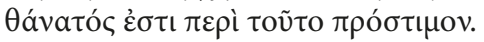

"A proof of this ${ }^{46}$ is that at Carthage candidates for office practice open bribery, whereas at Rome death is the penalty for it."

The question is what Polybius has in mind. He may refer to a certain law, or to an instance of prosecution conducted in an extraordinary court (a quaestio extraordinaria or a comitial trial) not necessarily in conformity with some law. ${ }^{48}$ The problem is that there is no evidence for death penalty for bribing voters either in the time of Polybius, or before. I have looked in vain for any court de ambitu before $116 \mathrm{BCE} .{ }^{49}$ As for the laws, we know of two dating before the 2 nd c. BCE (Liv. 4, 25 et 7, 15, 12-13), both dubious. They concern electioneering, but not bribery, and there is no mention of any penalty in the sources. The two laws from the early $2^{\text {nd }}$ c. BCE (Liv. $40,19,11^{50}$ and Epit. $47^{51}$ ) are only mentioned, and there is no evidence on their contents. ${ }^{52}$ One cannot exclude both that in the times of Polybius a certain law did inflict death penalty for bribing of voters and that it could form an extraordinary committee of judges. However, it is easier to suppose, that, at least in practice, in the 2 nd c. BCE death penalty was not imposed for this; any mention of it may date back to some point in early history and a practice fallen out of use. ${ }^{53}$ The idea

44 Schol. Bob. 78-79 Stangl lists of the laws on electioneering see in Hartmann 1894, 1801; Mommsen $1899,873-875$.

45 We are grateful to V.K. Khrustaljev for all the said in this paragraph.

46 I.e. of the fact that the Romans consider an inappropriate profit to be the worst shame.

47 Trans. Paton 1979.

48 The discussed passage of Polybius can be understood as concerning not a purchasing of votes but some other kind of bribe, but even then we can't illustrate it with any examples.

49 The only case, which could be related to ambitus - the investigation of C. Maenius quoted n. 56, has nothing to do with bribing.

${ }^{50}$ Et legem de ambitu consules ex auctoritate senatus ad populum tulerunt. See Stolle 1997, 64-65; Mommsen 1899, 866, n. 6.

${ }^{51}$ Lex de ambitu lata. The law is mostly referred to as lex Cornelia Fulvia. Both the date (159 BCE) and the authorship of the law (the consuls Cn. Cornelius Dolabella and M. Fulvius Nobilior) seem to be generally accepted (Berger 1925a, 2344-2345; Broughton 1951, 445; Hartmann 1894, 1801; Lange ${ }^{3} 1879$, 312; Rotondi 1912, 288 et al.). As far as I can understand, the date is lead from the fact, that the law is mentioned between the praetorship of Cn. Tremellius (Broughton 1951, 428) 159 BCE and the census of the same year; this is supported by Plinius' note, that the censors tried to limit the ambitio (NH. 34, 14). See Rinkes 1854, 47-52.

52 But both laws were linked to the cited passage: Walbank 1957, 741 (doesn't make choice between the two laws)); Hartmann 1894, 1801 votes for 159 BCE;. Lange ${ }^{3} 1879,312,663$ and, following him, Rotondi 1912, 288 conclude from the cited passage of Polybius, that the law of 159 BCE might have toughened up the penalty by prescribing a banishment. But Өávatos may mean death penalty, and in Polybius' time the exile was not a punishment, but a method of avoiding it, cf. e. g. Kunkel 1963, 766-768; Kleinfeller 1909, 1684; Levy 1931, 5-14.

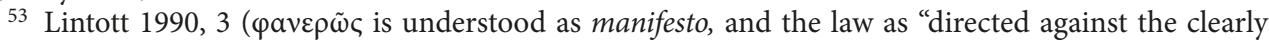
attested giving of bribes by the candidate himself"). Mommsen 1899, 668-669 cites these words of Polybius among the sources concerning the three kinds of fraud, for which, in Mommsen's view, was fixed death 
of an appeal to the people against condemnation for bribing the same people seems to be a good target for criticism. The Gracchi would not gain a lot by promulgating such a law. To sum up, it was but useless for the Gracchi to introduce a provocatio on the sentence of quaestiones perpetuae. At best it can be explained as a demagogic step, - and only if it concerned the quaestio inter sicarios.

The extraordinary committees were set up to ensure a speedy court procedure. Provocatio would have rendered them useless. An extraordinary court could be set up by ruling of either the senate or the public assembly. ${ }^{54}$ In the latter case, a clause excluding an appeal could be introduced into the bill setting up the court; in the former case the senate would need a separate law. Thus, at first sight, a law on provocatio against the rulings of extraordinary trials could affect the interests of the senate. Before the murder of Tiberius Gracchus the senate did decree an extraordinary trial in case of high-profile crimes potentially disrupting the law and order, but not in case of political crimes. ${ }^{55}$ Hence an introduction of provocatio against extraordinary courts was of no evident advantage to Tiberius Gracchus. One may proffer a guess that that was his way of safeguarding himself and his advocates against possible baiting on the part of the senate should there be no tribunus plebis ready for intercession. This measure seems, however, to fit better in the wake of the murder of Tiberius Gracchus when the senate did rule a series of extraordinary court trials to be held against his advocates, thus reaching out for this long unused measure in political struggle. ${ }^{56}$ As for Gaius Gracchus, it is known that the first thing he did was to pass the law prohibiting the summoning of extraordinary courts otherwise than by ruling of the popular assembly; this was his answer to the attacks on the advocates of Tiberius Gracchus. ${ }^{57}$ With this law adopted, it would have been useless to introduce provocatio against extraordinary trial courts. Consequently, the most appropriate time for such a project must be 132-122 BCE, and it might be the Tiberius' supporters, who considered it.

penalty in the 12 Tables (namely, perjury, purchasing of votes and of court decision). But Mommsen's interpretation lacks parallels.

${ }^{54}$ For the 2nd c. BCE cf. Polyb. 6, 16, 1-2: "The senate ... cannot carry out inquiries into the most grave and important offences against the state, which are punishable with death, and their correction, unless the senatus consultum is confirmed by the people" (Trans. Paton 1979). See Walbank 1957, 690-691. Polybius may have in mind only the quaestiones, which took place in Rome and investigated the crimes of the Roman citizens. For investigating the crimes of Italics the senate did not need a decision of the people (cf. Polyb. 6, 13, 4 and 7; Walbank 1957, 679-680). Polybius could mean the review of the commission's judgment by the people or the right of appeal against it. But such a view would not fit the evidence, on which see Ungern-Sternberg 1970, 29-38. Polybius could also have in mind not a custom, but the lex Sempronia of the 123 BCE: as Walbank, 1972, 11-13 suggests, in 118 BCE he could still be working on his "History". I am very grateful for this remark to A. Verlinsky. Whether the approval of the people was needed in the concrete case or not may have depended both on the position of tribuni plebis and of the senate. Cf. e.g. Liv. 4, 50-51: the tribunes vetoed the SC, and the senate asked them for a plebiscite. The passage is the only source on the case, which reports this fact (see Broughton 1951, 75), but if Livy invented it, he might have used a well-known scheme.

${ }_{55}$ In the $2^{\text {nd }}$ c. BCE the "political" crimes could be investigated only after the voting of the people. See literature quoted in n. 55. In the earlier time the senate might need no approval of the people (Kunkel 1963, 732), but it's rather difficult to cite any sources. The only attested case concerning a "political" crime might be the consular investigation of coitiones, which was ordered by the senate after resignation of the dictator C. Maenius (314 BCE), who had begun the inquiry. See Liv. 9, 26 and Oakley 1998, 319-320 (coitiones); Oakley 2005, 318-322 about C. Maenius. Kunkel 1963, 732 suggests convincingly that also the quaestio caedis Postumianae of the 413 BCE might be appointed not by the plebs (Liv. 4, 51), but by the senate. Cf. Ogilvie 1965, 611-612.

56 See Ungern-Sternberg 1970, 43.

57 I am convinced by Ungern-Sternberg 1970, 50-54 concerning the content of the law. See Kuznetsova 2017, 284 for the discussion of the sources. 
Thus, Plutarch's testimony can be interpreted in two ways. If the Gracchan bill concerned the senatorial quaestiones extraordinariae, it could have been discussed as a necessary measure against political prosecution, and such a measure could have been especially appealing after a series of persecutions of the advocates of Tiberius Gracchus. There is nothing in this reform that is exceptional or reprehensible. In any case, even if the provocatio was normally directed against coercitio, there is a slim chance that a speeded court procedure in such trials made provocatio against them natural even from the legal viewpoint. ${ }^{58}$ In Plutarch we witness a description of a bill distorted beyond recognition (the question remains whether it was intended ${ }^{59}$ ) and the whole idea is not very convincingly attributed to Tiberius.

The second possibility is that the alleged bill dealt with some other court. In this case it is easier to criticize this law, than to put forward arguments in its favour: it is difficult to think of beneficent consequences it could have had; apart from the reference to the civic value of the right for provocatio, it is hardly possible to justify this law as such. As we have seen, provocatio in murder trials could be attractive for common people, if they were not aware of possible consequences of such a law. Yet more likely is the possibility that the bill was ascribed to Tiberius Gracchus by a source hostile to Gracchi. To introduce the provocatio was, in fact, in most cases useless and even dangerous: it could harm the interests of the various strata of society and give the senate a good argument in propaganda. Hence, it is very probable that the author of this testimony aimed at representing Tiberius Gracchus as cunning and unprincipled demagogue, caring not if there could be point in the alleged bill and what content it could have.

\section{References}

Alexander M. C. Trials in the Late Roman Republic, 149 BC to 50 BC. Toronto, Toronto University Press, 1990. Berger A. Lex Cornelia Fulvia de ambitu, in: RE 1925, XII/2, 2344-2345 (a).

Berger A. Leges Serviliae, in: RE 1925, XII/2, 2414-2415 (b).

Bleicken J. Kollisionen zwischen Sacrum und Publicum: Eine Studie zum Verfall der Altrömischen Religion. Hermes 1957 (85, 4), 446-480.

Bleicken J. Ursprung und Bedeutung der Provocation. ZSS. Romanistische Abteilung 1959, 76, 324-377.

Botsford G. W. The Roman Assemblies from their Origin to the End of the Republic. NY, The Macmillan Company, 1909.

Briscoe J. A commentary on Livy. Books 41-45. Oxford, Clarendon Press, 2012.

Broughton T.R.S. The magistrates of the Roman Republic. Vol. 1. NY, The American Philological Association, 1951.

Cary E. (transl.). Dio's Roman History. Vol.2. Fragments of Books XII-XXV. Cambridge, MA, Harvard University Press, 1989.

Cloud D. The Constitution and Public Criminal Law, in: CAH 1994, IX, 491-530.

Crawford M.H. (ed.) Roman Statutes. Vols. 1-2. London, Institute of Classical Studies, 1996.

Damon C., Mackay Chr. On the Prosecution of C. Antonius in 76 B. C. Historia 1995, 44/1, 37-55. https:// repository.upenn.edu/classics_papers/48 (15.04.2018).

58 See the beginning of this article. This depends on whether the quaestiones extraordinariae could be regarded as caedes civis indemnati. Against this possibility is Kunkel 1963, 733. See, however, UngernSternberg 1970, 36-37 with n. 57.

59 If Plutarchs' reference stems from anti-Gracchan propaganda (see further), the bill on appeal against senatorial courts could hardly be described in an appropriate way: the bill was justified more than it was needed by what happened after the murder of Tiberius Gracchus. How dangerous any mention of it might be for the optimates, one could see, e. g., from the polemic around the execution of the Catilinarians contra legem Semproniam. 
Fraccaro P. Studi sull' età dei Gracchi. La tradizione storica sulla rivoluzione graccana. Fasc. 1. Castello, Casa editrice S. Lapi, 1914.

Gabba E. (ed., transl., comm.) Appiani Bellorum civilium liber primus. Firenze, Nuova Italia, 1958.

Hartmann L. M. Ambitus, RE 1894. I/1, 1800-1803.

Kleinfeller, G. Exilium, in: RE 1909, VI/2, 1683-1685.

Kleinfeller G. Repetundarum crimen, in: RE 1914, I/1A, 603-610.

Kunkel W. Untersuchungen zur Entwicklung des römichen Komitialverfahrens in vorsullanischer Zeit. München, Verlag der Bayerischen Akademie der Wissenschaften, 1962.

Kunkel W. Quaestio, in: RE 1963, XXIV, 720-786.

Kuznetsova N. Provocatio gegen das Urteil der duumviri perduellionis. Hyperboreus 2017, 23/2, 276-301.

Lange L. Römische Alterthümer. Bd. 2. Berlin, Weidmannsche Buchhandlung, ${ }^{3} 1879$. (Repr. 1974).

Lapyrenok R. V. Nasledie agrarnogo zakona Tiberiia Grakkha : zemelnyi vopros i politicheskaia bor'ba v Rime. [The Legacy of the Agrarian Law of Tiberius Gracchus: the Land Issue and the Political Struggle in Rome of the 120s BC.] Moscow, he Russian Foundation for Assistance to Education and Science 2016 (in Russian).

Leemann A. D., Pinkster H., Rabbie H. (Hg.) M. Tullius Cicero. De Oratore libri III: Kommentar. Bd. 3. Heidelberg, Carl Winter, 1989.

Levy E. Die römische Kapitalstrafe. Heidelberg, Carl Winter, 1931.

Lintott A. W. Provocatio. From the Struggle of the Orders to the Principate, in: ANRW 1972, I/2, 226-267.

Lintott A. W. Electoral Bribery in the Roman Republic. JRS 1990, 80, 1-16.

Lintott A. W. Political History, 146-95 B. C., in: CAH 1994, IX, 40-103.

Malcovati H. (ed.) Oratorum Romanorum Fragmenta. In 3 voll. Aug. Taurinorum, In aedibus Io. Bapt. Paraviae et sociorum, 1930.

Marshall B. A. A Historical Commentary on Asconius. Columbia, University of Missouri Press, 1985.

Meyer H. (ed., comm.) Oratorum Romanorum Fragmenta ab Appio inde Caeco et M. Porcio Catone usque ad Q. Aurelium Symmachum. Turici, Typis Orelli Fuesslini et sociorum, ${ }^{2} 1842$.

Mommsen Th. Römisches Strafrecht. Leipzig, Dunker u. Humboldt, 1899.

Mommsen Th. Römisches Staatsrecht. Bd. 1. Leipzig, Verlag von S. Hirzel, ${ }^{3} 1887$.

Münzer F. P. Cornelius Scipio Aemilianus Africanus, in: RE 1900, IV/1, 1439-1462 (a).

Münzer F. C. Sempronius Gracchus, in: RE 1923, II/2A, 1375-1400 (b).

Münzer F. Ti. Sempronius Gracchus, in: RE 1923, II/2A, 1409-1426.

Oakley S. A commentary on Livy. Books VI-X. Vol. 2. Books VII-VIII. Oxford, Clarendon Press, 1998.

Oakley S. A commentary on Livy. Books VI-X. Vol. 3. Book IX. Oxford, Clarendon Press, 2005.

Ogilvie R. M. A commentary on Livy, Books 1-5. Oxford, Clarendon Press, 1965.

Paton W. R. (transl.) Polybius. The Histories. Vol.3. Cambridge, MA, Harvard University Press, 1979.

Perrin B. (transl.) Plutarch's lives. Agis and Cleomenes, Tiberius and Gaius Gracchus, Philopoemen and Flamininus. Cambridge, MA, Harvard University Press 1988.

Rinkes S.H. Disputatio de crimine ambitus et de sodaliciis apud Romanos tempore liberae reipublicae. Lugduni Batavorum, Brill, 1854.

Rotondi G. Leges publicae populi Romani: elenco cronologico con una introduzione sullattività legislativa dei comizi romani. Milano, Società editrice libraria, 1912.

Schulten A. Numantia, in: RE 1936, XVII/1, 1254-1270.

Sherwin-White A. N. The Roman Citizenship. Oxford, Clarendon Press, ${ }^{2} 1973$.

Stockton D. The Gracchi. Oxford, Clarendon Press, 1979.

Stolle R. Ambitus et invidia. Römische Politiker im Spannungsfeld zwischen persönlichem Ehrgeiz und Forderungen der Standesloyalität 200-133 v. Chr. Berlin, Peter Lang, 1997.

Ungern-Sternberg von Pürkel J. Untersuchungen zum spätrepublikanischen Notstandsrecht: Senatusconsultum ultimum und hostis-Erklärung. München, C. H. Beck, 1970.

Walbank F. W. A Historical Commentary on Polybius. Vol. 1. Oxford, Clarendon Press, 1957.

Walbank F. W. Polybius. Berkeley, University of California Press, 1972.

Watts N.H. (transl.). Cicero. Pro Archia. Post reditum in senatu. Post reditum ad Quirites. De domo sua. De haruspicum responsis. Pro Plancio. Cambridge, Harvard University Press, 1923 (repr. 1993).

Wesener G. Promulgatio, in: RE 1962, Suppl. IX, 1239-1241.

Wesener G. Quaestor, in: RE 1963, XXIV/1, 801-827.

Received: February 15, 2019

Accepted: April 21, 2019 